\title{
Analisis Integrasi Pembiayaan Sektor Pertanian dan Nilai Tukar Petani di Indonesia
}

\author{
Hafiizh Maulana $^{* a}$, Evy Iskandar ${ }^{* b}$ \\ * Ekonomi Syariah FEBI UIN Ar-Raniry Banda Aceh \\ a Corresponding author: hafiizh.maulana2@gmail.com \\ $b$ iskandarevy@yahoo.com
}

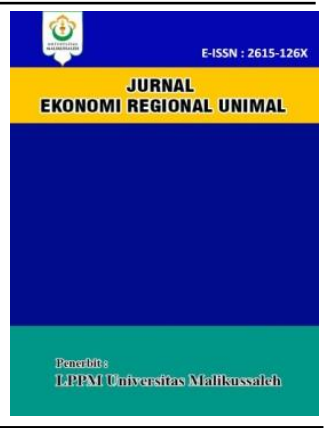

A R T I CLE I N F O RMATION

Keyword:

Financing, Agricultural sector, Islamic Banking

\section{A B S T R A C T}

This study aims to identify the relationship between the financing performance of the Islamic banking sector and the Farmer Exchange Rate in Indonesia. The analysis used the Vector Error Correction (VECM) Model from January 2009 until December 2017. The results of the tests consider the determinants of other variables in the form of non-performing financing and the credit based on interest rate. Agricultural sector financing, in the long run, has a significant effect on increasing Farmer Exchange Rate, but this influence is not responsive in the short term. The findings predict that Non-performing financing will reduce the proportion of financing in the agricultural sector to Islamic banks. Determination of Basic Interest Rates of Credit is the most responsive variable to the changes in the financing of Islamic banking and Farmer Exchange Rates in Indonesia.

\section{Pendahuluan}

Perbankan syariah sebagai lembaga intermediasi keuangan memiliki fungsi utama sebagai penyalur dana dari pihak yang kelebihan dana kepada pihak yang membutuhkan dana melalui proses pembiayaan. Penyaluran pembiayaan yang tepat sasaran akan mampu memberikan keuntungan bagi bank secara institusi dan kinerja sektor perekonomian secara makro. Berbeda dengan bank konvensional, bank syariah malakukan fungsi penyaluran dana dalam skema pembiayaan. Praktik pembiayaan yang dilakukan oleh lembaga keuangan syariah ini mendapat respon dari Dewan Syariah Nasional Majelis Ulama Indonesia (DSN-MUI) dalam mengeluarkan produk hukum berupa Fatwa No. 115/DSNMUI/IX/2017 dan No. 114/DSN-MUI/IX/2017.

Ketentuan-ketentuan yang diatur oleh DSN MUI sejauh ini belum mengatur secara spesifik mengenai distribusi sektor ekonomi yang menjadi prioritas dalam pembangunan perekonomian dari tingkat pusat sampai daerah. kecenderungan yang terjadi adalah, pembiayaan yang menggunakan akad lembaga keuangan syariah masih menyentuh pada sektor perdagangan dan jasa untuk meminimalisir tingkat resiko usaha yang besar. Pada sisi lain, usaha tani yang menjadi penopang perekonomian masyarakat belum tersentuh secara menyeluruh dalam skim pembiayaan perbankan syariah.

Menurut Beik dan Aprianti (2013) salah satu permasalahan mendasar yang dihadapi oleh sektor pertanian di Indonesia adalah ketersediaan kredit (pembiayaan). Pada kenyataannya, tidak semua pembiayaan yang disalurkan tersebut bebas dari risiko, dikarekan adanya risiko dalam pengembalian pembiayaan yang tidak tepat waktu dan macet. Bank Indonesia dalam Peraturan Bank Indonesia (PBI) nomor 3/1/2011 menetapkan tingkat kesehatan Bank Umum dapat dinilai dari profil risiko bank secara inheren dengan kualitas penerapan manajemen risiko pengkreditan perbankan. Skeptis inilah yang menimbulkan keengganan bagi bank syariah untuk memasuki pasar aktivitas usaha tani yang memiliki tingkat resiko yang tinggi. 
Data pembiayaan sektor pertanian yang bersumber dari OJK menujukkan adanya ketimpangan distribusi pembiayaan berdasarkan sektor lapangan pada bank syariah dan unit usaha syariah. Berdasarkan data pembiayaan bank syariah selama periode tahun 2014-2017, terlihat adanya gejala pembiayaan yang terkonsentrasi pada sektor lapangan usaha tersier. Lapangan usaha tersiser ini terdiri dari sektor perdagangan besar dan eceran, perantara keuangan, transportasi, pergudangan, komunikasi, real estate, usaha persewaan, dan jasa perusahaan. Konsentrasi pembiayaan ini berdasarkan data pembiayaan sektoral OJK (2017) berkontribusi bagi lapangan usaha mencapai rata-rata 30 persen dari total pembiayaan yang disalurkan.

Pembiayaan di Sektor pertanian yang dilirik oleh perbankan syariah masih sangat kecil, dengan kontribusi hanya dibawah 4 persen. Hal yang paradoks ini bertolak belakang dengan posisi pertanian sebagai penopang kegiatan ekonomi masyarakat di Indonesia. Kemampuan pembiayaan sektor pertanian mengalami kenaikan pada tahun 2015, namun pada periode 2016-2017 mengalami penurunan dengan pada Kisaran -3 \% (OJK, 2017)

Kurangnya pembiayaan sektor pertanian menjadi penyebab menurunnya pangsa sektor pertanian dalam lingkup Produk Domestik Bruto Indonesia. Salah satu masalah kurangnya pembiayaan sektor pertanian oleh sektor keuangan adalah anggapan bahwa sektor pertanian merupakan sektor usaha yang memiliki resiko sangat tinggi dibandingkan dengan sektor usaha yang lainnya (Thoha \& Saptia, 2009). Alasannya inilah menjadi indikasi penyebab akses petani terhadap penyaluran pembiayaan masih kecil.

Melihat kondisi rendahnya penyaluran pembiayaan sektor pertanian, perlu adanya telaah mendalam mengenai pembiayaan sektor yang mampu mereduksi kendala-kendala yang ada. Umumnya, kajian dilakukan menetapkan variabel Non Perfoming Finance (NPF) sebagai determinan dalam pembiayaan. Permasalahan risiko kredit yang bermasalah merupakan bentuk ketidakmampuan debitur dalam melunasi sebagian atau seluruh pembayaran pinjaman yang diberikan bank.
Untuk melihat adanya gejala penurunan kredit dan pembiayaan sektor pertanian, maka hal utama yang berkaitan langsung dengan tingkat kesejahteraan petani adalah Nilai Tukar Petani (NTP). Nilai tukar petani menggambarkan tingkat daya tukar/daya beli petani terhadap produk yang dibeli/dibayar petani yang mencakup konsumsi dan input produksi yang dibeli (Bappenas, 2013). Semakin tinggi nilai tukar petani, semakin baik daya beli petani terhadap produk konsumsi dan input produksi tersebut, dan berarti secara relatif lebih sejahtera. Data berikut ini ditampilkan perbandingan NTP, NPL dan NPF pembiayaan pada sektor pertanian di Indonesia.

\section{Gambar 1.}

\section{Grafik Perbandingan NTP, NPL, dan NPF Indonesia Tahun 2016 di Indonesia}

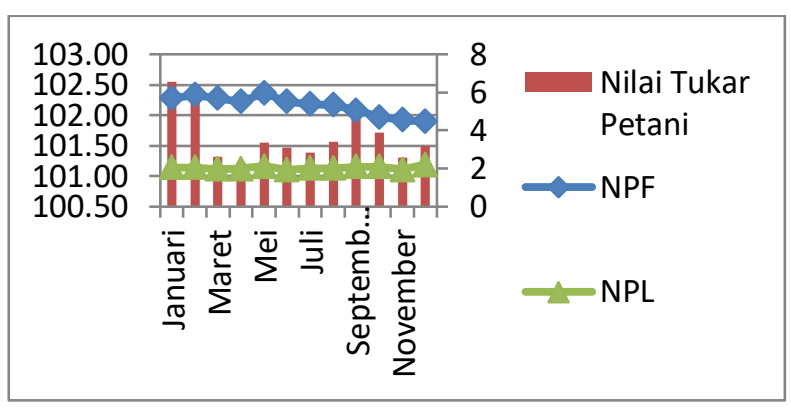

Sumber: Diolah dari data BPS RI, Statistik Perbankan Indonesia, dan Statistik Perbankan Syariah Indonesia, 2017

Kekhawatiran yang timbul dari data perbandingan grafik 2 adalah adanya penurunan NTP yang diikuti dengan tingginya kredit dan pembiayaan bermasalah pada sektor pertanian. Penurunan NTP terjadi pada bulan Maret-Juli yang diikuti pula penurunan pada bula OktoberDesember. Jika melihat data penurunan NTP pada bulan-bulan ini, diindikasikan pertanian Indonesia belum responsif terhadap musim tanam dan musim panen. Hal ini pula yang memberikan deskripsi awal bahwa peningkatan resiko kredit dan pembiayaan bermasalah karena adanya gejala penurunan NTP.

Pembiayaan bermasalah sektor pertanian secara umum mengalami penurunan, namun data NPF masih berada pada posisi 4-5 persen. nilai NPF dan NPL yang berada di atas 5 persen 
merupakan batas tolerasi nilai kredit/pembiayaan bermasalah yang ditetapkan oleh Bank Indonesia. Situasi ini perlu ditelaah lebih mendalam dalam pergerakan data yang lebih komplek untuk melihat keseimbangan jangka panjang dengan model estimasi Vector Auto Regression (VAR). Model pembiayaan pertanian sangat penting diterapkan dalam upaya meningkatkan pembiayaan sektor pertanian, khususnya komoditas pangan dan hortikultura. Otoritas Jasa Keuangan dalam penerbitan data Statistik Perbankan Syariah, mengklasifikan sektor pertanian dalam kelompok tanaman pangan, kehutanan, dan perburuan.

Berdasarkan fenomena yang telah dikemukakan, maka perlu adanya telaah mendalam mengenai pembiayaan sektor pertanian pada Bank Syariah. Berdasarkan latar belakang dan permasalahan yang diuraikan, maka penting bagi penelitian ini untuk menjawab serangkaian rumusan masalah berikut: (1) Bagaimana hubungan jangka panjang dan jangka pendek antara kinerja pembiayaan perbankan syariah sektor pertanian terhadap Nilai Tukar Petani (NTP) di Indonesia?

\section{TINJAUAN TEORITIS}

Pertanian memiliki peran penting dalam proses pembangunan perekonomian. Arifin (2003) menjelaskan bahwa Pertanian merupakan penyelamat pertumbuhan perekonomian Indonesia pada masa terjadinya keterpurukan akibat krisis ekonomi yang berkepanjangan. Dari keunggulan komparatif yang dimilikinya, pertanian memegang peran penting dalam perdagangan bebas, mengingat produk-produk pertanian memiliki kandungan lokal (local content) yang besar dibandingkan dengan komoditi manufaktur (Saragih, 2000). Dukungan lembaga keuangan syariah perlu dilakukan dalam mengupayakan petani mampu memperoleh akses pembiayaan guna meningkatkan input, proses, dan ouput usaha $\operatorname{tani}$

Acuan penetapan suku bunga dilakukan dalam suatu mekanisme kebijakan moneter $B I$ Rate melalui penetapan Suku Bunga Dasar Kredit (SBDK). BI Rate merupakan ukuran biaya modal yang harus dikeluarkan oleh pelaku usaha atau suatu perusahaan untuk menggunakan dana dari para investor, naiknya tingkat suku bunga dapat menarik perhatian investor untuk menyimpan uangnya di bank, tingkat suku bunga yang terlampau tinggi akan mempengaruhi aliran kas perusahaan, sehingga kesempatan-kesempatan untuk berinvestasi yang ada tidak akan menarik lagi (Mankiw, 2007).

Apabila BI Rate meningkat maka akan memicu turunnya aktivitas pembiayaan perbankan pada sektor lapangan usaha, dan begitu juga sebalinya. Ashari dan Sapthana (2005) menjelaskan, salah satu sifat yang melekat pada skim kredit pertanian yang berpeluang menimbulkan ketidakefektifan sehingga bank masih enggan memberikan kredit adalah timbulnya basis bunga tetap (fix interest), sementara sektor pertanian memiliki risiko kegagalan yang tinggi baik dalam produksi maupun fluktuasi harga yang relatif tinggi. Hal inilah yang menimbulkan kesenjangan (gap) antara sektor riil dan sektor moneter.

Salah satu komponen utama pertimbangan bank syariah dalam menyalurkan suatu pembiayaan adalah kemampuan dalam mengelola resiko usaha. Sektor pertanian sering dianggap kurang responsif terhadap perubahan iklim dan pasar yang mengakibatkan tingginya resiko usahatani. Karim (2009) memaparkan bahwa secara umum, risiko-risiko yang ada pada aktivitas fungsional bank syariah dapat diklasifikasikan ke dalam 3 jenis risiko, yaitu risiko pembiayaan, risiko pasar, dan risiko operasional. Akses permodalan pada usahatani yang rentan terhadap resiko-resiko inilah yang mengakibatkan tingginya NPF.

OJK (2015) melakukan suatu telaah pertumbuhan ekonomi ditinjau dari kredit perbankan menunjukkan bahwa Penurunan kinerja beberapa komoditas pertanian disebabkan adanya masalah tata niaga, edukasi petani, dan belum diterapkannya aturan mengenai bahan olahan pertanian, sehingga kredit sektor pertanian belum dapat mendorong pertumbuhan ekonomi secara signifikan. Adanya suatu dugaan kuat bahwa tataniaga pertanian menjadi sebab melemahnya posisi pendapatan petani. Jika NTP meningkat 
maka pembiayaan sektor pertanian akan memberikan kepastian pengembalian dan menghidari dari resiko pembiayaan.

Relevansi utama NTP dengana akses pembiayaan adalah guncangan yang terjadi pada pembiayaan bermasalah/macet yang dikenal dengan Non Performing Financing (NPF).Pembiayaan bermasalah menggambarkan suatu situasi dimana persetujuan pengembalian kredit mengalami risiko kegagalan, bahkan cenderung menuju atau mengalami kerugian yang potensial (potensial loss). Berdasarkan Peraturan Bank Indonesia Nomor 18/14/PBI/2016 Tentang Giro Wajib Minimum Bank Umum Dalam Rupiah Dan Valuta Asing Bagi Bank Umum Konvensional, dijelaskan bahwa rasio NPL terhadap total kredit tidak boleh lebih dari $5 \%$.

Berkaitan dengan hubungan NPF dengan pembiayaan pertanian, ditelaah dengan analisis respon variabel melalui uji transmisi oleh Mughits dan Wulandari (2016). Ketika terjadi peningkatan rasio pembiayaan macet (NPF), maka cenderung akan mengurangi pembiayaan yang disalurkan oleh perbankan syariah khususnya untuk sektor pertanian. Akan tetapi kelamahan analisis ini belum memperkuat argumentasi pembiayaan macet dalam skala mikro yang menguji hubungan jangka panjang antara NTP dengan pembiayaan bermasalah pada sektor pertanian. Maka masih muncul tanda tanya lemahnya akses petani dalam hal pembiayaan sebagai akibat dari turunnya pendapatan petani.

Beik dan Aprianti (2013) melakukan estimasi dengan model VAR/VECM berkaitan dengan faktor-faktor yang mempengaruhi pembiayaan bank syariah sektor pertanian di Indonesia. Hasil yang diperoleh menunjukkan bahwa Non Performing Financing (NPF) tidak memengaruhi pembiayaan pertanian, baik pada jangka pendek maupun jangka panjang. Penelitian ini merekomendasikan peningkatan proporsi pembiayaan pertanian seiring dengan peningkatan jumlah dana pihak ketiga, peningkatan kompetensi SDM perbankan syariah yang menguasai sektor pertanian, dan penguatan instrumen kebijakan moneter syariah
Khan, dkk (2007) melakukan permodelan kredit bermasalah sektor pertanian dalam jangka pendek di Bank Zarrai Tarraqiati di Pakitstan, menghasilkan temuan bahwa Peningkatan produksi per satuan luas lahan akan semakin memperluas akses kredit dalam jangka pendek dan meningkatkan penyaluran kredit sehingga sejumlah besar petani bisa mendapatkan keuntungan dari program kredit. Secara supply side memperlihatkan bahwa program pengkreditan sektor pertanian sangat responsi terhadap produksi komoditas sektor pertanian.

\section{METODE PENELITIAN}

Desain penelitian menggunakan analisis kuantitatif dengan basis time series kinerja perbankan syariah sektor pertanian dan NTP selama periode Januari 2009 sampai Desember 2017. Penelitian menggunakan analisis time series model VAR (Vector Autoregression)/VECM (Vector Error Correction Model). Model ini secara spesifik mampu melihat mengestimasi hubungan jangka pendek dan panjang dengan mempertimbangkan asumsi stationer, kointegrasi, dan tingkat lag optimum.

\section{Definisi Operasional}

Variabel utama dalam penelitian ini terdiri dari Kinerja Perbankan syariah dan NTP yang diukut berdasarkan beberapa konsep definisi operasiona. Berikut ini definisi operasional dari masing-masing-masing variable

\begin{tabular}{|c|c|c|}
\hline Variabel & Indikator & Ukuran \\
\hline \multirow[t]{3}{*}{$\begin{array}{l}\text { Kinerja } \\
\text { Pembiayaan } \\
\text { Perbankan } \\
\text { Syariah }\end{array}$} & $\begin{array}{lr}\text { Jumlah } & \text { alokasi } \\
\text { pembiayaan perbankan } \\
\text { syariah pada sektor } \\
\text { pertanian }\end{array}$ & (Rp.) \\
\hline & $\begin{array}{l}\text { Pembiayaan } \\
\text { bermasalah sektor } \\
\text { pertanian yang diukur } \\
\text { dari nilai persentase } \\
\text { Non Performing } \\
\text { Financing (NPF) }\end{array}$ & $\%$ \\
\hline & $\begin{array}{lr}\text { BI Rate } & \text { yang } \\
\text { menggambarkan } & \text { Suku } \\
\text { bunga acuan } & \text { Kredit } \\
\text { Perbankan } & \text { yang } \\
\text { ditetapan oleh } & \text { Bank }\end{array}$ & $\%$ \\
\hline
\end{tabular}




\begin{tabular}{|l|l|l|}
\hline & Indonesia (SBDK) & \\
\hline Nilai Tukar & rasio antara harga yang & Rasio \\
Petani & diterima petani (HT) & \\
& dengan harga yang & \\
& dibayar petani (HB) & \\
\hline
\end{tabular}

\section{Model Analisis}

Model VAR (Vector Autoregressive) I VECM (Vector Error Correction Model) digunakan untuk menganalisis ada tidaknya saling ketergantungan antara pembiayaan sektor pertanian pada bank syariah dengan NTP sebagai indikator kesejahteraan petani. Model VAR/VECM adalah suatu sistem persamaan yang memperlihatkan setiap variabel sebagai fungsi linier dari konstanta dan nilai lag (lampau) dari variabel itu sendiri serta nilai lag dari variabel lain yang ada di dalam sistem.. Adapun model VAR dari integrasi pembiayaan sektor pertanian dengan NTP sebagai berikut:

$$
\begin{aligned}
\operatorname{PSP}_{\mathrm{t}}= & \alpha_{1}+\delta_{1} \mathrm{t}+\phi_{11} \mathrm{PSP}_{\mathrm{t}-1}+\ldots+\phi_{1 \mathrm{p}} \mathrm{PSP}_{\mathrm{t}-} \\
& \mathrm{p}+\beta_{11} \mathrm{NTP}_{\mathrm{t}-1}+\ldots+\beta_{1 \mathrm{q}} \mathrm{NTP}_{\mathrm{t}-\mathrm{q}}+ \\
& \beta_{12} \mathrm{NPF}_{\mathrm{t}-1}+\ldots+\beta_{1 \mathrm{r}} \mathrm{NPF}_{\mathrm{t}-\mathrm{r}}+ \\
& \beta_{13} \mathrm{BIRATE}_{\mathrm{t}-1}+\ldots+\beta_{1 \mathrm{~s}} \mathrm{BIRATE}_{\mathrm{t}-\mathrm{s}}+ \\
& \varepsilon_{\mathrm{t}} \ldots(1) \\
\mathrm{NTP}_{\mathrm{t}}= & \alpha_{2}+\delta_{2} \mathrm{t}+\phi_{21} \mathrm{NTP}_{\mathrm{t}-1}+\ldots+\phi_{2 \mathrm{p}} \\
& \mathrm{NTP}_{\mathrm{t}-\mathrm{p}}+\beta_{21} \mathrm{PSP}_{\mathrm{t}-1}+\ldots+\beta_{1 \mathrm{q}} \mathrm{PSP}_{\mathrm{t}-\mathrm{q}} \\
& +\beta_{22} \mathrm{NPF}_{\mathrm{t}-1}+\ldots+\beta_{1 \mathrm{r}} \mathrm{NPF}_{\mathrm{t}-\mathrm{r}}+ \\
& \beta_{23} \text { BIRATE }_{\mathrm{t}-1}+\ldots+\beta_{1 \mathrm{~s}} \text { BIRATE }_{\mathrm{t}-\mathrm{s}}+\varepsilon_{\mathrm{t}}
\end{aligned}
$$

$\mathrm{NPF}_{\mathrm{t}}=\alpha_{3}+\delta_{3} \mathrm{t}+\phi_{31} \mathrm{NPF}_{\mathrm{t}-1}+\ldots+\phi_{3 \mathrm{p}} \mathrm{NPF}_{\mathrm{t}-}$

$$
\begin{aligned}
& \mathrm{p}+\beta_{31} \mathrm{PSP}_{\mathrm{t}-1}+\ldots+\beta_{1 \mathrm{q}} \mathrm{PSP}_{\mathrm{t}-\mathrm{q}}+\beta_{32} \mathrm{NTP}_{\mathrm{t}-} \\
& { }_{1}+\ldots+\beta_{1 \mathrm{r} N T P} \mathrm{NT}_{\mathrm{t}-\mathrm{r}}+\beta_{33} \text { BIRATE }_{\mathrm{t}-1}+\ldots+ \\
& \beta_{1 \mathrm{~s}} \text { BIRATE }_{\mathrm{t}-\mathrm{s}}+\varepsilon_{\mathrm{t}}
\end{aligned}
$$

BIRATE $_{\mathrm{t}}=\alpha_{4}+\delta_{4} \mathrm{t}+\phi_{41} \mathrm{BIRATE}_{\mathrm{t}-1}+\ldots+$

$$
\begin{aligned}
& \phi_{4 \mathrm{p}} \text { BIRATE }_{\mathrm{t}-\mathrm{p}}+\beta_{41} \mathrm{PSP}_{\mathrm{t}-1}+\ldots+ \\
& \beta_{1 \mathrm{q}} \mathrm{PSP}_{\mathrm{t}-\mathrm{q}}+\beta_{42} \mathrm{NTP}_{\mathrm{t}-1}+\ldots+\beta_{1 \mathrm{r}} \mathrm{NTP}_{\mathrm{t}-\mathrm{r}}+ \\
& \beta_{43} \mathrm{NPF}_{\mathrm{t}-1}+\ldots+\beta_{1 \mathrm{~s}} \mathrm{NPF}_{\mathrm{t}-\mathrm{s}}+\varepsilon_{\mathrm{t}}
\end{aligned}
$$

keterangan

PSP = Pembiayaan Sektor Pertanain $(\mathrm{Rp})$

NTP = Nilai Tuka Petani(Indeks)

$\mathrm{NPF}=$ Non Performing Financing (\%)

Birate $=$ Suku Bunga dasar Kredit Bank Indonesia
Tahapan pengolahan data dengan menggunakan model VAR/VECM harus dilakukan terlebih dahulu serangkaian pengujian yang terdiri dari:

\section{Uji Stationeritas}

Langkah pertama yang harus dilakukan dalam estimasi model ekonomi dengan data time series adalah dengan menguji stasioneritas pada data atau disebut juga stationary stochastic process. Kestasioneran diperlukan untuk menghindari adanya spurious regression (regresi palsu). Suatu persamaan dikatakan stasioner apabila memiliki mean, variance, dan covariance yang konstan pada setiap lag dan tidak mengandung unit root. Uji stasioneritas data ini dapat dilakukan dengan menggunakan Augmented Dickey-Fuller (ADF) pada derajat yang sama (level atau different) hingga diperoleh suatu data yang stasioner, yaitu data yang variansnya tidak terlalu besar dan mempunyai kecenderungan untuk mendekati nilai rata-ratanya (Enders, 1995).

Widarjono (2012) menjelaskan bahwa fungsi uji ADF adalah untuk melihat ada tidaknya trend di dalam pergerakan data yang akan diuji. Uji ADF terdiri dari perhitungan regresi yang dirumuskan sebagai berikut.

$$
\begin{aligned}
& \Delta \mathrm{Y}_{\mathrm{t}}=\gamma \mathrm{Y}_{\mathrm{t}-1}+\beta_{\mathrm{i}} \sum_{\mathrm{t}=1}^{\rho} \Delta \mathrm{Y}_{\mathrm{t}-\mathrm{i}}+\varepsilon_{\mathrm{t}} \ldots \ldots \ldots \ldots \ldots \ldots \ldots \ldots \ldots \ldots \\
& \Delta \mathrm{Y}_{\mathrm{t}}=\alpha_{0}+\gamma \mathrm{Y}_{\mathrm{t}-1}+\beta_{\mathrm{i}} \sum_{\mathrm{t}=1}^{\rho} \Delta \mathrm{Y}_{\mathrm{t}-\mathrm{i}}+\varepsilon_{\mathrm{t}} \ldots \ldots \ldots \ldots \ldots \\
& \Delta \mathrm{Y}_{\mathrm{t}}=\alpha_{0}+\alpha_{1} \mathrm{t}+\gamma \mathrm{Y}_{\mathrm{t}-1}+\beta_{\mathrm{i}} \sum_{\mathrm{t}=1}^{\rho} \Delta \mathrm{Y}_{\mathrm{t}-\mathrm{i}}+\varepsilon_{\mathrm{t}}
\end{aligned}
$$

dimana :

$$
\begin{array}{lll}
\Delta \mathrm{Y}_{\mathrm{t}} & =\text { Selisih variabel }\left(\mathrm{Y}_{\mathrm{t}}-\mathrm{Y}_{\mathrm{t}-1}\right) \\
\gamma & =(\rho-1) \\
\alpha_{0}, \alpha_{1}, \gamma, \beta_{\mathrm{i}}= & \text { Koefisien } \\
\mathrm{t} & \text { Trend waktu (2008Jan-2017Des) } \\
\mathrm{Y} & \text { Variabel yang diuji } \\
& \text { stasioneritasnya (Pembiayaan } \\
& \text { Perbankan Syariah sektor } \\
& \text { pertanian), Nilai Tukar Petani } \\
= & \text { Panjang lag yang digunakan } \\
\mathrm{P} & & \text { dalam model } \\
& = & \text { Error persamaan }
\end{array}
$$




\section{Uji Kointegrasi (Johansen Cointegration Test)}

Uji kointegrasi bertujuan untuk menentukan apakah variabel-variabel yang tidak stationer terkointegrasi atau tidak. Konsep kointegrasi yang dikemukakan oleh Engle Granger sebagai kombinasi linear dari dua atau lebih variabel yang tidak stationer dan menghasilkan variabel yang stationer. Kombinasi linear ini dikenal dengan istilah persamaan kointegrasi dan dapat diinterpretasikan sebagai hubungan keseimbangan jangka panjang di antara variabel (Firdaus, 2011). Pengujian kointegrasi dalam penelitian ini menggunakan pendekatan uji Johansen. Uji Johansen dilakukan dengan membandingkan antara nilai trace statistic dengan nilai critical value dan maximum eigenvalue dengan critical value pada taraf nyata 5\%. Jika trace statistic atau maximum eigenvalue lebih besar dari critical value maka mengindikasikan bahwa dalam sistem persamaan terdapat hubungan jangka panjang atau kointegrasi. Uji yang dilakukan adalah trace test yaitu mengukur jumlah vektor kointegrasi dalam data dengan menggunakan pengujian pangkat matriks kointegrasi yang dinyatakan sebagai berikut (Enders 1995) :

$\lambda_{\text {trace }(\mathrm{r})}=-\mathrm{T} \sum_{\mathrm{t}=\mathrm{r}+1}^{\mathrm{n}} \ln \left(1-\lambda_{\mathrm{t}}\right)$

$\lambda_{\max (\mathrm{r}, \mathrm{r}+1)}=-\mathrm{T} \ln \left(1-\lambda_{\mathrm{r}+1}\right)$.

dimana:

$\lambda_{\mathrm{t}}=$ Nilai dugaan akar karakteristik (eigenvalues) yang didapatkan dari estimasi matriks $\pi$

$\mathrm{T}=$ Jumlah observasi

$\mathrm{r}$ = Pangkat yang mengindikasikan jumlah vektor kointegrasi

Pada uji $\lambda$ trace, $\mathrm{H}_{0}$ adalah jumlah vektor kointegrasi yang hilang $\leq \mathrm{r}$ sebagai alternatif umum. Jika $\lambda$ trace $<\lambda$ tabel maka terima $\mathrm{H}_{0}$ yang artinya kointegrasi terjadi pada rank r. Sementara pada uji $\lambda \max , \mathrm{H}_{0}$ yaitu jumlah vektor kointegrasi $=\mathrm{r}$ adalah alternatif dari vektor kointegrasi $\mathrm{r}+1$ (Enders, 1995).

\section{Uji Kausalitas Granger}

Uji kausalitas Granger dilakukan untuk melihat hubungan kausalitas di antara variabelvariabel yang ada dalam model. Pengujian hubungan sebab akibat, dalam pengertian Granger (1969) dalam Firdaus (2011) dilakukan dengan menggunakan F-test untuk menguji apakah lag informasi dalam variabel Y memberikan informasi statistik yang signifikan tentang variabel $\mathrm{X}$ dalam menjelaskan perubahan X. Jika tidak, maka Y tidak ada hubungan sebab akibat Granger dengan $\mathrm{X}$ Dalam penilitian ini, uji kausalitas digunakan untuk melihat hubungan antara pembiayaan perbankan syariah sektor pertanian dengan Nilai Tukar Petani di Indonesia.

\section{HASIL PENELITIAN DAN PEMBAHASAN}

Analisa transmisi pembiayaan perbankan syariah sektor pertanian terhadap Nilai Tukar Petani di Indonesia dibangun dari suatu hipotesa pembuktian hubungan jangka pendek dan jangka panjang. Adapun komponen variabel untuk membuktikan hipotesa model transmisis adalah Jumlah total pembiayaan bank syariah untuk sektor pertanian (PSP), persentase pembiayaan bermasalah/macet (NPF), Suku Bunga Dasar Kredit (SBDK), dan Nilai Tukar Petani (NTP). Sebelum ditelaah lebih lanjut perlu dilakukan terlebih dahulu pengujian persyaratan analisa yang terdiri dari uji stationer, kointegrasi, dan kausalitas.

\section{Uji Stationer}

Tes stasioner dilakukan dengan uji Augmented Dickey-Fuller (ADF) pada first different. Hasil pengolahan data menunjukka bahwa dengan persamaan individual intercept keseluruhan variabel dinyatakan stationer pada first different. Hal ini ditunjukkan oleh nilai probability untuk masing-masing variabel sebagaimana ditampilkan dalam tabel berikut ini.

Tabel 2

Hasil Pengujian Stationer

\begin{tabular}{|l|l|c|l|}
\hline Variabel & Differenced & $\begin{array}{c}\text { Tes } \\
\text { ADF }\end{array}$ & Kesimpulan \\
\hline PSP & $\begin{array}{l}\text { first } \\
\text { difference }\end{array}$ & $\begin{array}{c}- \\
11,56^{* * *}\end{array}$ & stationer \\
\hline NTP & first & $-8,04 * * *$ & Stationer \\
\hline
\end{tabular}




\begin{tabular}{|l|l|l|l|}
\hline & difference & & \\
\hline NPF & $\begin{array}{l}\text { first } \\
\text { difference }\end{array}$ & $-11,7 * * *$ & Stationer \\
\hline SBDK & $\begin{array}{l}\text { first } \\
\text { difference }\end{array}$ & $-6,76 * * *$ & Stationer \\
\hline
\end{tabular}

Data Diolah dengan E-Vews

Keterangan: *significant pada $90 \%$, **significant pada $95 \%$, ***significant pada $99 \%$

Berdasarkan hasil uji unit root test, pembiayaan bank syariah, PDB, dan tenaga kerja masing-masing stationer pada first different.. Hasil pengujian ini menyimpulkan bahwa ketiga variabel tidak mengadung unit akar. Ketiga variabel tersebut dapat dilanjutkan untuk pengujian integrasi dengan terlebih dahulu membuktikan apakah data terkointegrasi atau tidak.

\section{Uji Kointegrasi}

Sebelum melakukan pengujian model VAR/VECM terlebih dahulu dilakukan pengujian kointegrasi data dengan menggunakan teknik pengujian Johansen Cointegration. Uji kointegrasi dilakukan Untuk mengetahui apakah terdapat hubungan jangka panjang antara 4 variabel yang diteliti. Tes kointegrasi berguna untuk prasyarat berikutnya dalam analisis transmisi Pembiayaan dengan model VECM. Tes kointegrasi ini menggunakan Johansen Test, dengan membandingkan nilai Trace Statistic (TS) dan Maximum Eigenvalue (ME) terhadap nilai $t$ statistik. Bila nilai TS dan ME lebih besar dari nilai $t$-statistik, maka hipotesis nol ditolak dan artinya kedua variabel saling terkointegrasi. Hasil tes kointegrasi dapat ditampilkan sebagai berikut:

\section{Tabel 3}

\section{Hasil Pengujian Johansen Kointegrasi}

\begin{tabular}{|r|c|c|c|}
\hline Parameter & Nilai & $\begin{array}{c}\text { Nilai kritis } \\
\mathbf{5 \%}\end{array}$ & Keterangan \\
\hline Trace Statistic & $53,6^{* * *}$ & 47,86 & ta Terkointgrasi \\
\hline $\begin{array}{r}\text { Mx-Eigen } \\
\text { Statistic }\end{array}$ & $30,26 * *$ & 27,58 & ta Terkointgrasi \\
\hline
\end{tabular}

Data Diolah dengan E-Vews

Keterangan: *significant pada $90 \%, * *$ significant pada $95 \%$, ***significant pada $99 \%$

$$
\text { Berdasarkan hasil pengujian }
$$

kointegrasi,diketahui bahwa terdapat hubungan kointegrasi (integrasi jangka panjang) antara Pembiayaan sektor pertanian, NPF, NTP, dan SBDK. Adapun kritetia parameter nilai TS dan ME signifikan dan lebih besar nilainya dibandingkan nilai kritis (critical value 5\%). Hal ini menunjukan bahwa data saling terkointegrasi, yaitu memiliki hubungan keseimbangan jangka panjang. Dengan demikian analisa transmisi kinerja pembiayaan perbankan Syariah sektor pertanian dan NTP dapat dilanjutkan ke tahap pengujian selanjutnya, yaitu pengujian model Vector Error Correction Model (VECM).

\section{Uji Kausalitas}

Tes kausalitas bertujuan untuk memastikan arah hubungan integrasi antara pembiayaan perbankan syariah sektor pertanian, NPF, NTP, dan SBDK. Dalam penelitian ini, tes kausalitas dilakukan dengan menggunakan metode Granger Caucality Test . hubungan yang searah atau dua arah akan menggambarkan apakah terdapat hubungan sebab akibat antar kinerja pembiayaan sektor pertanian terhadap Nilai Tukar Petani di Indonesia. Adapun hasil pengujian kausalitas Granger dapat dilihat pada tabel di bawah ini.

Tabel 4

Hasil Pengujian Kausalitas Granger

\begin{tabular}{|c|c|c|c|}
\hline \multicolumn{2}{|c|}{$\begin{array}{c}\text { Hubungan Kausalitas } \\
\text { Variabel }\end{array}$} & \multirow{2}{*}{$\begin{array}{c}\text { F- } \\
\text { Statis } \\
\text { tik }\end{array}$} & \multirow{2}{*}{$\begin{array}{l}\text { Kesimpulan } \\
\text { Terdapat } \\
\text { hubungan }\end{array}$} \\
\hline \multirow[t]{2}{*}{$\begin{array}{l}\text { NPF dan } \\
\text { NTP }\end{array}$} & $\begin{array}{l}\text { NPF } \\
\rightarrow \text { NTP }\end{array}$ & & \\
\hline & $\begin{array}{l}\text { NTP } \\
\rightarrow \text { NPF }\end{array}$ & $1.83 *$ & $\begin{array}{l}\text { searah yang } \\
\text { signifikan, } \\
\text { NTP } \\
\text { dipengaruhi } \\
\text { oleh NPF }\end{array}$ \\
\hline \multirow[t]{2}{*}{$\begin{array}{l}\text { PSP dan } \\
\text { NTP }\end{array}$} & $\begin{array}{l}\text { PSP } \\
\rightarrow \text { NTP }\end{array}$ & 1.05 & \multirow{2}{*}{$\begin{array}{l}\text { Tidak ada } \\
\text { hubungan } \\
\text { kausalitas }\end{array}$} \\
\hline & $\begin{array}{l}\text { NTP } \\
\rightarrow \text { PSP }\end{array}$ & 1.35 & \\
\hline \multirow[t]{2}{*}{$\begin{array}{l}\text { SBDK dan } \\
\text { NTP }\end{array}$} & $\begin{array}{l}\text { SBDK } \\
\rightarrow \text { NTP }\end{array}$ & 1.26 & \multirow{2}{*}{$\begin{array}{l}\text { Tidak ada } \\
\text { hubungan } \\
\text { kausalitas }\end{array}$} \\
\hline & $\begin{array}{l}\text { NTP } \\
\rightarrow \text { SBDK }\end{array}$ & 0.49 & \\
\hline \multirow[t]{2}{*}{$\begin{array}{l}\text { PSP dan } \\
\text { NPF }\end{array}$} & $\begin{array}{l}\text { PSP } \\
\rightarrow \mathrm{NPF}\end{array}$ & 0.53 & \multirow{2}{*}{$\begin{array}{l}\text { Terdapat } \\
\text { hubungan } \\
\text { searah yang } \\
\text { signifikan, }\end{array}$} \\
\hline & $\begin{array}{l}\text { NPF } \\
\rightarrow \text { PSP }\end{array}$ & $\begin{array}{c}2.36^{*} \\
*\end{array}$ & \\
\hline
\end{tabular}




\begin{tabular}{|c|c|c|c|}
\hline & & & $\begin{array}{l}\text { NPF } \\
\text { dipengaruhi } \\
\text { oleh PSP }\end{array}$ \\
\hline \multirow[t]{2}{*}{$\begin{array}{l}\text { SBDK dan } \\
\text { NPF }\end{array}$} & $\begin{array}{l}\text { SBDK } \\
\rightarrow \text { NPF }\end{array}$ & $\begin{array}{c}3.92 * \\
* *\end{array}$ & \multirow{2}{*}{$\begin{array}{l}\text { Terdapat } \\
\text { hubungan } \\
\text { searah yang } \\
\text { signifikan, } \\
\text { SBDK } \\
\text { dipengaruhi } \\
\text { oleh NPF }\end{array}$} \\
\hline & $\begin{array}{l}\text { NPF } \\
\rightarrow \text { SBDK }\end{array}$ & 1.15 & \\
\hline \multirow[t]{2}{*}{$\begin{array}{l}\text { SBDK dan } \\
\text { PSP }\end{array}$} & $\begin{array}{l}\text { SBDK } \\
\rightarrow \text { PSP }\end{array}$ & 1.04 & \multirow{2}{*}{$\begin{array}{l}\text { Terdapat } \\
\text { hubungan } \\
\text { searah yang } \\
\text { signifikan, PSP } \\
\text { dipengaruhi } \\
\text { oleh SBDK }\end{array}$} \\
\hline & $\begin{array}{l}\text { PSP } \\
\rightarrow \text { SBDK }\end{array}$ & $1.86^{*}$ & \\
\hline
\end{tabular}

Data Diolah dengan E-Vews

Keterangan: $* * *=$ significant pada taraf $1 \%, * *=$ significant pada taraf $5 \%$ dan $*=$ significant pada pada taraf $10 \%$

Berdasarkan uji kausalitas variabel dengan menggunakan grager causality test, dapat dijelaskan bahwa secara umum hubungan kausalitas yang terbentuk antar masing-masing variabel bersifat searah. Hubungan yang searah ini menggambarkan bahwa perubahan yang terjadi antara 1 variabel dengan variabel lain direspon tanpa adanya hubungan timbal balik. Atau dengan kata lain kinerja pembiayaan perbankan syariah dalam rentang waktu jangka panjang cenderung merespon perubahan pada sisi arah yang berbeda beda.

Hasil pengujian tidak membuktikan adanya hubungan kausalitas antar jumlah pembiayaan sektor pertanian terhadap NTP. Gejala awal dari uji kausalitas ini ialah, proporsi bank syariah dalam mengalokasi pembiayaan disektor pertanian tidak didasarkan atas Nilai Tukar Petani. Adapun hasil yang diperoleh dalam uji kausalitas ini seakan-akan memberikan argumentasi bahwa akses petani dalam pembiayaan perbankan syariah masih lemah. Kinerja usaha tani yang digambarkan oleh peningkatan NTP diindikasikan lebih karena adanya kebijakan bantuan dan subsidi dari pemerintah. Artinya peran perbankan syariah dalam mengucurkan pembiayaan disektor pertanian tidak salah berkaitan. Hal yang sama juga terjadi pada perubahan kebijakan SBDK yang menegasi perubahan pada NTP. Maka temuan awal dalam penelitian ini, tidak membuktikan adanya hubungan sebab akibat antara sisi kebijakan SBDK dengan NTP.

Hubungan searah yang signifikan terjadi pada variabel NTP dengan NPF. Hubungan Kausalitas yang terbentuk pada kedua variabel ini adalah hubungan searah, di mana NTP dipengaruhi oleh NPF. Hubungan searah ini menggambarkan bahwa terjadinya pembiayaan bermasalah pada sektor pertanian dapat disebabkan karena perubahan pada NTP. Namun perubahan yang terjadi pada NTP tidak secara langsung direspon oleh perubahan pada NPF. Maka salah satu kebijakan mengatasi resiko usaha pada sektor pertanian harus mempertimbangkan aspek pendapatan petani yang secara makro dapat diukur dari NTP.

Pembiayaan bermasalah sektor pertanian dapat terjadi dari berbagi sisi dan faktor, sehingga kompleksitas dari naik/turunnya pembiayaan bermasalah sektor pertanian juga terjadi pada variabel lain. Berdasarkan hasil uji hubungan kausalaitas, ditemukan hubungan yang signifikan antara NPF terhadap jumlah proporsi pembiayaan sektor pertanian dan kebijakan SBDK Bank Indonesia. Gejala hubungan sebab akibat yang muncul adalah, NPF dipengaruhi oleh kebijakan pembiayaan sektor pertanian yang sejatinya memiliki resiko usaha yang tinggi. Disisi yang lain, kebijakan SBDK Bank Indonesia secara signifikan dipengaruhi oleh pembiayaan permasalah atau NPF. Hubungan kausalitas seakan-seakan memberikan indikasi adanya kebijakan pembiayaan bank syariah yang sangat hat-hati pada sektor pertaian

Hubungan kausalaitas belum memberikan argumentasi yang kuat bahwa kinerja pembiayaan perbakan syariah tidak responsif terhadap Nilai Tukar Petani. Setidaknya, model pengujian dan analisis transmisi perlu membuktikan hubungan jangka pendek dan jangka panjang respon dari masing-masing variabel.

\section{Analisis Hubungan Jangka Panjang dan Jangka Pendek}

Hasil analisis berikutnya akan menguji hubungan jangka panjang dan jangka pendek 
perubahan yang terjadi pada pembiayaan perbankan syariah sektor pertanian terhadap pergeseran NTP. Uji analisis sebelumnya, sudah membuktikan bahwa data pada tiap variabel stationer pada first different dan terkointegrasi, maka model dilanjutkan dengan analisa time series VECM. Hasil output estimasi dapat ditampil dalam tabel sebagai berikut.

\section{Table 5}

Hubungan Jangka Panjang dan Jangka Pendek

\begin{tabular}{|c|c|c|c|c|}
\hline $\begin{array}{l}\text { Cointegratin } \\
\text { g Eq }\end{array}$ & $\begin{array}{l}\text { Coint } \\
\text { Eq1 }\end{array}$ & $\begin{array}{l}\text { Coint } \\
\text { Eq2 }\end{array}$ & $\begin{array}{c}\text { CointE } \\
\text { q3 }\end{array}$ & $\begin{array}{c}\text { CointE } \\
\text { q4 }\end{array}$ \\
\hline \multirow[t]{3}{*}{$\operatorname{NTP}(-1)$} & \multirow[t]{3}{*}{1.000} & $\begin{array}{c}339,8 \\
9\end{array}$ & 0,163 & $-17,721$ \\
\hline & & $\begin{array}{c}(147,5 \\
7)\end{array}$ & $(0,07)$ & $(8,09)$ \\
\hline & & $\begin{array}{c}{[2,303} \\
]\end{array}$ & {$[-2,32]$} & $\begin{array}{c}{[-} \\
2,189]\end{array}$ \\
\hline \multirow[t]{3}{*}{$\operatorname{PSP}(-1)$} & 0,003 & \multirow[t]{3}{*}{1.000} & 0,0005 & $-0,052$ \\
\hline & $\begin{array}{l}(0,00 \\
09)\end{array}$ & & $\begin{array}{c}(0,000 \\
0)\end{array}$ & $(0,006)$ \\
\hline & $\begin{array}{c}{[} \\
3,257]\end{array}$ & & {$[5,36]$} & $\begin{array}{c}{[-} \\
9,292]\end{array}$ \\
\hline \multirow[t]{3}{*}{ SBDK(-1) } & 6,125 & $\begin{array}{l}2081 \\
75\end{array}$ & \multirow[t]{3}{*}{1.000} & 108,54 \\
\hline & $\begin{array}{c}(1,327 \\
)\end{array}$ & $\begin{array}{c}(276,0 \\
49)\end{array}$ & & $\begin{array}{c}(15,911 \\
)\end{array}$ \\
\hline & $\begin{array}{c}{[4,617} \\
]\end{array}$ & $\begin{array}{c}{[7,541} \\
)\end{array}$ & & $\begin{array}{c}{[-} \\
6,821]\end{array}$ \\
\hline \multirow[t]{3}{*}{ NPF (-1) } & $-0,056$ & $-19,18$ & $-0,009$ & \multirow[t]{3}{*}{1,000} \\
\hline & $\begin{array}{c}(0,015 \\
)\end{array}$ & $(1,69)$ & $(0,002)$ & \\
\hline & $\begin{array}{c}{[-} \\
3,78]\end{array}$ & $\begin{array}{c}{[-} \\
11,34 \\
5]\end{array}$ & {$[-5,92]$} & \\
\hline $\mathrm{C}$ & $\begin{array}{c}- \\
142,0 \\
6\end{array}$ & $\begin{array}{c}- \\
48285 \\
, 97\end{array}$ & 23,195 & $\begin{array}{c}2517,5 \\
4\end{array}$ \\
\hline
\end{tabular}

Data Diolah dengan E-Vews

Keterangan: Standard errors in ( ) \& t-statistics in [ ].

Hasil ouput estimasi jangka pendek dan jangka panjang panel VECM dapat dituliskan dalam empat persamaan struktural sebagai berikut:

$$
\begin{aligned}
\text { NTP }= & -142,06+0,003 \mathrm{PSP}_{t-1}+ \\
& 6,125 S B D K_{t-1}-0,056 \mathrm{NPF}_{t-1} \\
P S P= & -4285,97+339,89 \mathrm{NTP}_{t-1}+ \\
& 2081,75 S B D K_{t-1}-19,18 \mathrm{NPF}_{t-1} \\
S B D K= & 23,195+0,163 \mathrm{NTP}_{t-1}+ \\
& 0,0005 P S P_{t-1}-0,009 \mathrm{NPF}_{t-1}(3)
\end{aligned}
$$

$$
\begin{aligned}
N P F= & 2517,54-17,721 \mathrm{NTP}_{t-1}- \\
& 0,052 \mathrm{PSP}_{t-1}+108,54 \mathrm{SBDK}_{t-1}
\end{aligned}
$$

Model analisis VECM membentuk 4 persamaan struktural yang memperlihatkan hubungan jangan panjang dan pendek antar masing-masing variabel. Permbentukan persamaan ini didasarkan pada dugaan bahwa gejala perubahan pembiayaan sektor pertanian dan Nilai Tukar Petani seling berkaitan satu sama lain. Secara umum Arah koefisien menghasilkan tanda yang konsisten pada variabel pembiayaan sektor pertanian, NTP, dan SBDK. Nilai NPF menjadi variabel yang diduga terdapat sejumlah perbedaan pada penempatan model persamaan. Hal ini diduga kuat karena resiko pembiayaan sektor pertanian yang tinggi menjadi alasan utama bagi bank syariah dalam mengalokasikan sejumlah pembiayaan.

Pada model persamaan yang pertama dan kedua, perubahan pada kebijakan perbankan syariah pada sektor pertanian berpengaruh secara signifikan pada Nilai Tukar Petani. Respon perubahan yang terjadi adalah, apabila alokasi pembiayaan sektor pertanian meningkat maka gejala perubahan yang positif terjadi pada Nilai Tukar Petani. Hal serupa juga terjadi pada peningkatan perubahan Nilai Tukar Petani yang akan meningkatkan alokasi Pembiayaan sektor pertanian. Hubungan jangka panjang dan pendek dalam permodelan VECM ini menegaskan bahwa terdapat transmisi yang searah antara Pembiayaan sektor pertaniain dengan Nilai Tukar Petani.

Perubahan pada SBDK dan NPF merespon arah yang positif dan negatif pada persamaan 1 dan 2. Respon positif terjadi pada peningkatan SBDK, yang dapat mendorong penigkatan NTP dan alokasi pembiayaan sektor pertanian. Pertimbangan SBDK ini secara makro ekonomi dipengaruhi oleh kebijakan moneter bank sentral (BI) dalam penetapan tingkat suku bunga acuan. Maka dalam konteks ini, perubahan pada SBDK secara signifikan berpengaruh positif pada pembiayaan sektor pertanian dan NTP. Hubungan negatif terjadi pada pembiayaan bermasalah atau NPF yang mampu mereduksi NTP dan alokasi pembiayaan sektor pertanian. Peningkatan 
pembiayaan bermasalah sektor pertanian dapat mengakibatkan penurunan alokasi pembiayaan karena resiko pembiayaan menjadi salah satu pertimbangan bank syariah dalam kebijakan pembiayaan.

Model persamaan 3 dan 4 dijelaskan dalam hubungan jangka panjang yang menempatkan SBDK dan NPF sebagai unpredictor variable. Kebijakan SBDK BI mengalami peningkatan sebagai akibat dari respon pembiayaan sektor pertanian dan NTP yang meningkat. Hal ini konsisten berdasarkan persamaan struktural 1 dan 2, yang menjustifi adanya perubaha SBDK yang berhubungan searah dengan NTP dan Pembiayaan pertanian. Pada variabel NPF. Adanya dugaan peningkatan pembiayaan sektor pertanian dan NTP akan berdampak pada penurunan nilai NPF. Hubungan yang berbanding terbalik terjadi antara NPF dengan SBDK yang memperlihatkan adanya respon peningkatan NPF apabila SBDK meningkat, dan begitu juga sebaliknya NPF akan turun jika SBDK diturunkan.

Kinerja pembiayaan sektor pertanian pada Bank Syariah dengan Nilai Tukar Petani dalam pengujian hubungan jangka panjang memperlihatkan adanya skeptis bank syariah pada sisi pembiayaan bermasalah (NPF) dan kebijakan SBDK. Jika ditelusuri dalam suatu penjelasan umum, Nilai Tukar Petani memang menjadi pertimbangan dalam pembiayaan sektor pertaiain. Namun demikian, pertimbangan ini tidak mutlah terjadi karena pada sisi yang lain NPF yang meningkat akan terjadi sebagai akibat dari meningkatnya jumlah pembiayaan sektor pertanian. SBK juga turut mempengaruhi jumlah pembiayaan dan NPF, di mana SBDK ini dikhatirkan dapat meningkatkan NPF meskipun respon dari Nilai Tukar Petani Meningkat. Artinya dapat disimpulkan bahwa kebijakan alokasi pembiayaan sektor pertanian tidak hanya mempertimbangkan peningkatan pendapatan petani, namun adanya pertimbangan risk management dan SBDK dalam pengelolaan pembiayaan.

\section{Analisis Hubungan Jangka Pendek}

Analisa hubungan jangka panjang menghasilkan temuan menarik bahwa kinerja pembiayaan perbankan syariah responsif terhadap Nilai Tukar Petani. Namun dalam kaitannya dengan hubungan jangka pendek, bisa saja terjadi perbedaan respon. Hubungan jangka panjang mempertimbangkan adanya efek data yang stationer dan terkointegrasi. Pada hubungan jangka pendek, variabel dapat menangkap pengaruh yang berbeda-beda, dan cenderung tidak respon dalam periode yang singkat. Pada pengujian jangka pendek, pengujian difokuskan pada pengaruh kinerja pembiayaan sektor pertanian terhadap Nilai Tukar Petani. Maka dalam sistem permodelan yang diajukan, menempatkan Nilai Tukar Petani sebagai Dependent Variabel.

\section{Table 6}

Hubungan Jangka Pendek

\begin{tabular}{|c|c|c|c|c|}
\hline $\begin{array}{c}\text { Variabe } \\
1\end{array}$ & Coefficient & $\begin{array}{l}\text { Std. } \\
\text { Error }\end{array}$ & $\begin{array}{c}\text { t- } \\
\text { Stati } \\
\text { stic }\end{array}$ & Prob. \\
\hline $\operatorname{NTP}(-1)$ & 0.29 & 0.1001 & 2.891 & $\begin{array}{c}0.004 \\
8\end{array}$ \\
\hline $\mathrm{NTP}(-2)$ & -0.131 & 0.099 & $\begin{array}{c}- \\
1.314\end{array}$ & $\begin{array}{c}0.191 \\
9\end{array}$ \\
\hline $\mathrm{NPF}(1)$ & -0.0002 & 0.002 & $\begin{array}{c}- \\
0.086\end{array}$ & $\begin{array}{c}0.931 \\
8\end{array}$ \\
\hline $\mathrm{NPF}(-2)$ & -0.0005 & 0.002 & $\begin{array}{c}- \\
0.226\end{array}$ & $\begin{array}{c}0.821 \\
8\end{array}$ \\
\hline $\operatorname{PSP}(-1)$ & $-5.42 \mathrm{E}-05$ & 0.0002 & $\begin{array}{c}- \\
0.276\end{array}$ & $\begin{array}{c}0.783 \\
5\end{array}$ \\
\hline $\operatorname{PSP}(-2)$ & 9.99E-05 & 0.0002 & 0.511 & $\begin{array}{c}0.610 \\
8\end{array}$ \\
\hline $\begin{array}{l}\text { SBDK(- } \\
1)\end{array}$ & -0.656 & 0.287 & $\begin{array}{c}- \\
2.284\end{array}$ & $\begin{array}{c}0.024 \\
6\end{array}$ \\
\hline $\begin{array}{l}\text { SBDK(- } \\
1)\end{array}$ & 0.571 & 0.286 & 1.987 & $\begin{array}{c}0.049 \\
8\end{array}$ \\
\hline $\begin{array}{l}\text { Constant } \\
\mathrm{a}\end{array}$ & 0.032 & 0.056 & 0.578 & $\begin{array}{c}0.564 \\
6\end{array}$ \\
\hline \multicolumn{5}{|c|}{$\begin{array}{l}\text { R-Squared } 0,144 \\
\text { F-Stat } 1,773 \\
\text { Durbin Watson } 1,935\end{array}$} \\
\hline
\end{tabular}

Data Diolah dengan E-Vews 8.0

Persamaan model Panel VECM jangka pendek menghasil r-squared sebe sar 0,144 , Artinya determinasi dari hubungan persamaan dalam jangka pendek sebesar 14,4 \%sementara sisanya dipengaruhi oleh variabel lain. Pada tabel 
diatas menunjukkan bahwa dalam jangka pendek, NTP lebih dipengaruhi oleh dirinya sendiri, yaitu NTP pada periode 1 bulan sebelumnya. Apabila NTP periode sebulan sebelumnya meningkat, maka akan diikuti oleh peningkatan NTP Sebesar 0,29 point.

Jumlah pembiayaan dan NPF sektor pertanian tampak tidak responsif berpengaruh terhadap NTP, dimana pada masing-masing variabel tidak signifikan. Hasil ini mengartikan bahwa akses petani dari sisi NTP dalam memperoleh pembiayaan bank syariah tidak berpengaruh signifikan dalam jangka pendek. Maka kebijakan alokasi pembiayaan sektor pertanian tidak mempertimbangkan perubahan NTP dalam periode yang singkat. Atau dapat diduga skim pembiayaan sektor pertanian bank syariah mengambil jangka waktu masa pembiayaan dalam jangka panjang.

Kebijakan moneter melalui SBDK diduga paling mempengaruhi perubahan NTP, dengan tingkat kepercayaan nilai signifikansi pada periode 1 bulan dan 2 bulan sebelumnya sebesar p-value 95 persen SBDK berpengaruh negatif dan signifikan terhadap NTP pada periode 1 bulan sebelumnya dan positif pada periode 2 bulan sebelumnya. Hal ini menggambarkan bahwa petani sulit merespon kenaikan SBDK dalam mengakses pembiayaan maupun kredit perbankan. Pada sisi SBDK, acuan tidak hanya pada bank syariah namun juga kredit pada lembaga keuangan lainnya. Maka dapat dijustifikasikan perubahan Kebijakan moneter SBDK dapat mempengaruhi akses petani dalam memperoleh skema-skema kredit/pembiayaan pada lembaga keuangan

\section{KESIMPULAN}

Hubungan Pembiayaan sektor pertanian dengan Nilai Tukar Petani secara umum dilakukan dalam mekanisme transmisi kebijakan jangka panjang. Maka tidak tertutup kemungkinan fokus kebijakan pembiayaan dalam jangka panjang mempertimbangkan aspek Nilai Tukar Petani. Respon perubahan kebijakan pembiayaan sektor pertanian dapat mengalami transmisi pada periode waktu jangka panjang, yang juga diikuti oleh resiko nilai NPF sektor pertanian. Sektor pertanian juga dihadapkan pada tingkat resiko yang tinggi, dengan adanya temuan NPF mempengaruhi alokasi perbankan dalam menyalurkan pembiayaan sektor pertanian.

Hasil penelitian juga menyimpulkan bahwa pembiayaan sektor pertanian pada perbankan syariah tidak terlalu responsif pada Nilai Tukar Petani dalam periode jangka Pendek. Tingkat kesejahteraan petani berdasarkan ukuran Nilai Tukar Petani dalam hubungan jangka pendek, lebih dipengaruhi oleh sisi kebijakan sektor pertanian itu sendiri. Artinya, Nilai Tukar Petani di Indonesia dihadapkan pada persoalan kinerja sektor pertaniain yang belum responsif terhadap pembiayaan usaha tani.

Kebijakan Bank Syariah sejauh pengamatan dan hasil temuan yang diperoleh, terdapat keterkaitan yang erat dengan SBDK yang ditetapkan oleh Bank Indonesia. Bank Syariah dalam kebijakan pembiayaan tetap mempertimbangkan aspek moneter dalam penetapan SBDK sebagai acuan proporsi permbiayaan di sektor pertanian. Maka dapat disimpulkan pula, implikasi perubahan tingkat SBDK akan berdampak pada skema pembiayaan dan bagi hasil bank syariah di sektor pertanian.

\section{DAFTAR PUSTAKA}

Anshari dan Saptana. (2005). Prospek Pembiayaan Syariah untuk Sektor Pertanian. Jurnal Forum Penelitian Agro Ekonomi, Vol. 2, Desember 2005, hal 132-147.

Arifin, B. (2003), Spektrum Kebijakan Pertanian Indonesia: Telaah Struktur, Kasus, dan Alternatif Strategi, Jakarta: Penerbit Erlangga.

Bank Indoensia. (2016). Laporan Pilot Project Skma Pembiayaan Pertanain Melalui Penerapan Konsep Pembiayaan Rantai Nilai. Jakarta: Departemen Pengembangan UKM.

Bank Indonesia. Peraturan Bank Indonesia (PBI) Nomor 13/1/PBI/ 2011 tentang Penilaian Kesehatan Bank Umum. Tambahan Lembaran Negara Republik Indonesia Nomor 5184 DPNP. 
Beik, I. S., \& Aprianti, W. N. (2013). Analisis Faktor-faktor yang Mempengaruhi Pembiayaan Bank Syariah untuk Sektor Pertanian di Indonesia. Jurnal Agro Ekonomi. Volume 31. 1, Mei 2013: 19-36.

BPS. (2017), Statistik Pertanian. 2017, Jakarta: Badan Pusat Statistik

Enders, Walter. (1995). Applied Econometric Time Series. New York: John Wiley \& Sons.

Firdaus, M. (2011). Aplikasi Ekonometrika untuk Data Panel dan Time Series. Bogor: IPB Press.

Karim AA. (2009). Bank Islam: Analisis Fiqih dan Keuangan. Jakarta: Raja Grafindo Persada

Kementerian Perencanaan Pembangunan Nasional/Bappenas dan Japan International Agencey (JICA). (2013). Analisis Nilai Tukar Petani (NTP) sebagai Bahan Penyususnan RPJM tahun 2015-2019. Jakarta: Direktorat Pangan dan Pertanian Bappenaas.

Khan, dkk. (2007). The Effect of Short Term Agricultural Loans Scheme of Zarai Tarraqiati Bank on Increase in Farm Production in District Karak. Pakistan: Sarhad J. Agric Vol 23, No. 4, 2007.

Mankiw, N. Gregory. (2007). Makro Ekonomi, Edisi ke-6. Jakarta: Erlangga.

Mughits, Minhatul dan Wulandari, Ries. (2016). Kontribusi Pembiayaan Bank Syariah untuk Sektor Pertanian di Indonesia . Jurnal AlMuzara'ah Vol 4, No. 1, 2016.

Saragih, B. (2000), "Kebijakan Pertanian untuk Merealisasikan Agribisnis sebagai Penggerak Utama Perekonomian Negara", Paper on Panel Discussion, Center Policy for Agro Studies.

Thoha, M., \& Saptia, Y. (2009). Efektivitas Model Pembiayaan Syariah Dalam Mengembangkan Sektor Pertanian. Jakarta: LIPI Press, anggota Ikapi.

Widarjono A. (2012). Ekonometrika Pengantar dan Aplikasinya. Yogyakarta: Ekonisia.

www.ojk.go.id/id/kanal/syariah/data-danstatistik/statistik-perbankansyariah/Default.aspx. diakses pada tanggal 10 Juli 2018. 